\title{
Genetic Determinism in the Genetics Curriculum
}

\section{An Exploratory Study of the Effects of Mendelian and Weldonian Emphases}

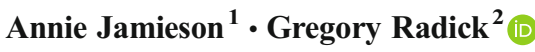

Published online: 6 July 2017

(C) The Author(s) 2017. This article is an open access publication

\begin{abstract}
Twenty-first-century biology rejects genetic determinism, yet an exaggerated view of the power of genes in the making of bodies and minds remains a problem. What accounts for such tenacity? This article reports an exploratory study suggesting that the common reliance on Mendelian examples and concepts at the start of teaching in basic genetics is an eliminable source of support for determinism. Undergraduate students who attended a standard 'Mendelian approach' university course in introductory genetics on average showed no change in their determinist views about genes. By contrast, students who attended an alternative course which, inspired by the work of a critic of early Mendelism, W. F. R. Weldon (18601906), replaced an emphasis on Mendel's peas with an emphasis on developmental contexts and their role in bringing about phenotypic variability, were less determinist about genes by the end of teaching. Improvements in both the new Weldonian curriculum and the study design are in view for the future.
\end{abstract}

Keywords Genetic determinism $\cdot$ Genetics teaching $\cdot$ Mendel $\cdot$ Weldon $\cdot$ Dominance

\section{Introduction}

'Battling the undead': that is how the philosopher Philip Kitcher memorably characterized the fight against genetic determinism (Kitcher 2001). It should have expired long ago, and yet, in small ways and larger, in the public as well as backstage cultures of science and medicine, it remains not just resilient but resistant to challenge (see, e.g. Moore 2008). We want here to endorse an increasingly well-confirmed diagnosis of the nature of the problem faced and also to propose a new form of therapy. In brief, our diagnostic hypothesis is that the Mendelian

Gregory Radick

G.M.Radick@leeds.ac.uk

1 National Science and Media Museum, Little Horton Lane, Bradford BD1 1NQ, UK

2 School of Philosophy, Religion and History of Science, University of Leeds, Leeds LS2 9JT, UK 
emphases typical of introductory genetics teaching at every level promote determinist attitudes which persist long after people learn that, in fact, genes are not destiny. The therapy that we recommend, on the basis of an exploratory study that we conducted at the University of Leeds in the autumn of 2013, is a course of introductory genetics that emphasizes not Mendelian patterns and principles but developmental contexts and phenotypic variability as the upshot of those contexts.

Section 2 introduces the historical source of our own perspective on Mendelism and determinism: the largely neglected writings of early Mendelism's most profound critic, W. F. R. Weldon. Section 3 then describes the exploratory study, which, along with the delivery of the new Weldonian curriculum, involved the gathering of pre- and post-intervention data on genetic determinism in two groups of undergraduate students: those taking the Weldonian course and those taking the standard, start-with-Mendel introductory genetics course. Section 4 reports and analyses the gathered data, quantitative and qualitative, with particular attention to our main finding: that whereas students attending the Mendelian course on average showed no change in their determinist views about genes, students attending the Weldonian course were less determinist about genes by the end of teaching. Sections 5 and 6 offer reflections on this finding and on next steps to improve both the design of the intervention and the Weldonian curriculum at its heart.

\section{The Weldonian Perspective}

There are more ways than one for a genetics curriculum to be 'non-Mendelian'. Not all of the possible options - imagine, say, a Lamarckian curriculum - are scientifically respectable in the twenty-first century. Among the scientifically respectable options, not all are concerned primarily with combatting genetic determinism. An excellent, up-and-running example is Rosie Redfield's 'Useful Genetics' MOOC. ${ }^{1}$ It grew out of her frustration with genetics teaching materials that, for all their patched-in updating, appeared to be hopeless at producing students who actually understood genetics (as distinct from being able to pass exams in it). She thus decided to start afresh, stripping out Mendelism along with many other canonical topics in favour of molecular genetics and, as she put it in a manifesto, 'what [students] will need in their daily lives - a solid understanding of how genes influence phenotypes, of natural genetic variation, and of the mechanism of heredity' (Redfield 2012, p. 4).

By contrast, the non-Mendelian curriculum in the Leeds exploratory study, whilst also aiming to give students a 'useful genetics' introduction, did so by stressing that lots of things, not just genes, influence phenotypes; that natural phenotypic variation is wide and worth taking at least as seriously as natural genetic variation; and that the 'mechanism of heredity' is a developmental process, such that every inherited trait depends to some extent on interactions between the 'genes for' that trait and a developmental context, including not only other genes but also broader physiological and physico-chemical environments. Furthermore, where Redfield explicitly jettisoned what she called 'the historical approach' (Redfield 2012, p. 2), the Leeds curriculum took the inspiration for its content directly from the history of genetics.

The English biologist Walter Frank Raphael Weldon was, from 1899 until his death in 1906 at the age of 46, the Linacre Professor of Comparative Anatomy at Oxford (Magnello 2004; Pearson 1906). Nowadays, he is remembered chiefly for three things. He was a pioneer

$\overline{{ }^{1} \text { https://www.edx.org/course/useful-genetics-part-1-how-genes-shape-ubcx-usegen-1x-0 }}$ 
of the statistical description and analysis of natural populations, or 'biometry', notable in particular for his work demonstrating natural selection in the wild. He was, in the name of biometry, a leading opponent of the grander claims of the new 'Mendelism' as it emerged rapidly from 1900, following the famous rediscovery of Mendel's pea-hybrids paper that spring. And, in his role as Mendelian critic, he was the first to point out that, examined statistically, Mendel's data fit his theory a little too well. What recent historical study of Weldon's unpublished correspondence and manuscripts has begun to establish are the deeper concerns underlying that critical stance. When, in 1902, Weldon published a photograph showing that pea cotyledons were not, as per Mendel, either 'yellow' or 'green', but everywhere on the spectrum between those two colours, he meant to underscore a link he perceived between the overly capacious descriptive categories that Mendelism encouraged and the Mendelian concept of dominance as something permanently associated with a particular hereditary character, whatever the context (Weldon 1902a, b; Jamieson and Radick 2013; Radick 2015). For Weldon, that concept looked, in the light of the recent progress of biology (and especially experimental embryology), wholly untenable. The same character could be dominant or not dominant depending on what was interacting with what. Of course, if, following Mendel's example, an investigator deliberately excludes 'interfering' variation from a population under study - as Mendel did in purifying his breeding stocks - then the scope of those interactions will be much reduced. In a limited way, the resulting patterns can be illuminating, and Weldon thought Mendel's were. But what they show is not how inheritance really works - the mechanism of heredity — but how it works under highly unusual and, as far as natural populations go, entirely unrepresentative conditions.

Weldon's most sustained statement of this developmentalist, interactionist perspective on inheritance lies buried away in a manuscript entitled Theory of inheritance that he left unpublished and indeed uncompleted at his death in 1906 (Weldon 1904-1905). Extracts have recently appeared, and a scholarly edition is now in preparation (A. Jamieson \& G. Radick, W. F. R. Weldon's "theory of inheritance" manuscript, unpublished). More immediately, the Weldonian curriculum in introductory genetics has been developed as a means of addressing the question of the nature and scale of the difference that Weldon's perspective might have made to the subsequent history of genetics had he lived and been successful in promoting his views. Suppose present-day biology textbooks were the descendants of a history where Weldon had won the argument, or more so than he actually did. What would those textbooks look like? And what would the students who learned from them be like? In particular, would they be less prone to genetic determinism than the students coming out of a Mendelian curriculum? ${ }^{2}$

Needless to say, as a matter of principle, no one should need Weldon's example in order to construct a curriculum along the variability-and-context-emphasizing lines of the Leeds curriculum. A devoted reader of the collected works of Richard Lewontin (1982, 1991; also Rose et al. 1984) and Evelyn Fox Keller (2000, 2010, 2014) would be well placed and well motivated to come up with more or less the same thing. Other routes to the same destination run through the small but scorching critical literatures on the defects of 'dominance' talk (Allchin 2000, 2002, 2005; Falk 2001), 'gene for' talk (Kitcher 1995, ch. 11; Burian and Kampourakis 2013; Kampourakis 2017) and overreliance on monogenic traits in genetics teaching (Dougherty 2009; Lewis 2011). There is even a growing international body of work exploring the links between persistent genetic determinism and persistently Mendelian ways of

\footnotetext{
${ }^{2}$ Back in the day, Mendelians were unabashed about that determinism. William Bateson, Weldon's counterpart on the Mendelian side, reflected later in life that 'Scientific Calvinism' was not a bad shorthand for the Mendelian message (Bateson 1984, vi)
} 
teaching, talking and thinking about genetics (see, e.g. Gericke and Hagberg 2007, 2010a, b; Castéra et al. 2008a, b; Dougherty 2010; Dougherty et al. 2011; Santos et al. 2012; Gericke et al. 2013, 2014; Thörne and Gericke 2014; Smith and Gericke 2015; Aivelo and Uitto 2015). Yet in practice Weldon's example has been indispensable. Perhaps determinist Mendelism is so pervasively a part of what biology has become that the only way truly to escape its grip is to learn from thoughtful, well-informed people who were never in its grip in the first placefrom, that is, contemporary critic-witnesses such as Weldon. (It is striking that Fox Keller's The century of the gene, volubly brilliant on why the old gene concepts and language must go, fell silent on what should replace them.) ${ }^{3}$

A related point is that, historically considered, the Weldonian perspective did not so much disappear from genetics as take up permanent residence on the conceptual sidelines, where it became a kind of intellectual mascot: a colourful tag-a-long, worth putting in the spotlight from time to time to liven up proceedings, and even accumulating its own, small, slightly oddball fan club, but ultimately inconsequential and, when paid too much attention, tiresome. Thus, one reads early on in The mechanism of Mendelian heredity (1915), by T. H. Morgan and his students from the famous Columbia University fly room, that they take for granted as the essence of the Mendelian creed that 'every character is the realized result of the reaction of hereditary factors with each other and with their environment' (Morgan et al. 1915, p. 46). No big deal: and once stated, it need never be revisited, through pages and pages on chromosomes, Mendelian factors, and patterns of inheritance in experimental lineages.

Those who did make a fuss down the decades are a most heterogeneous bunch. ${ }^{4}$ So we find Hermann Muller, the great theorist in the Morgan group, insisting in writings of the 1930s and 1940s on the complexity of the relationship between genotype and phenotype, given genic interactions and environmental influences (Muller 1930, 1947). We find the entomologistturned-ethologist W. H. Thorpe, in a 1950 lecture on evolution and Christianity, observing in passing that 'we now know that genes including 'lethals' may have many different effects according to the gene complex in which they find themselves; and a gene which is conspicuously harmful in one stock or environment may, under different genetic or ecological conditions, be of real value' (Thorpe 1951, pp. 7-8). We find Lancelot Hogben, long-time champion of the importance of the 'nurture' side of nature-nurture controversies, calling in the 1960s for reform of genetics education in medicine founded on 'the realization of the immensely complex possibilities of interaction between nature and nurture at every stage in a development process rightly conceived as embracing the whole life cycle' (Hogben 1963, p. 75). And we find Sir Peter Medawar, in his sympathetic 1977 review of Leon Kamin's book on Cyril Burt and IQ in the New York Review of Books, explaining why the whole notion that a character can be partitioned into the inherited and the acquired is nonsense because, as the likes of Hogben and J.B.S. Haldane had made plain, 'the contribution of nature is a function of nurture and of nurture a function of nature, the one varying in dependence with the other, so that a statement that might be true in one context of environment and upbringing would not

\footnotetext{
${ }^{3}$ In response to an article on the Weldonian curriculum published in May 2016 in Nature (Radick 2016a), an American high-school science teacher wrote: 'Whenever teaching the conventional approach to genetics, I always felt the students did not fully appreciate the complexities of the interactions that occurred. I had never thought of approaching the topic as you describe, but it makes perfect sense'. (1 June 2016).

${ }^{4}$ An excellent analytical history of the interaction debates in post-Morgan biology is Tabery (2014). On the question of why the interactionist side never managed to quash genetic determinism culturally, see Esposito (2017), which documents the links in the twentieth century between genetic determinism and fantasies of technical control over genes. For that link's continued vitality (alongside Mendelism) in best-selling popular genetics in the twenty-first century, see Radick (2016b).
} 
necessarily be true in another'. Superb teacher that he was, Medawar went on to give compelling examples. In humans, the genes behind an inability to digest phenylalanine obey Mendelian rules; but the mental retardation associated with them-and so the condition, phenylketonuria, that those genes are 'for' — can be avoided by bringing up the affected child in a world free from phenylalanine, in which case the condition is at least as aptly described as environmental in origin. Or, he urged, consider eye colour in the brackish shrimp Gammarus chevreuxi. Some genetic combinations make eye colour appear to be wholly under environmental control; some ambient temperatures allow for patterns in colour inheritance conforming to Mendelian rules (Medawar 1977, pp. 171-172).

Imagine what genetic knowledge would look like if interaction was the main message, and scenarios in which interaction can (for certain purposes) be ignored are relegated to the margins. That imagined reorganization-with flipped centre and periphery, foreground and background, grand generalization and special case - is the vision behind the curriculum taught in an exploratory study in Leeds in autumn 2013. It is a 'Weldonian' curriculum in that Weldon's work on inheritance is the inspiration, though, for reasons set out later, neither Weldon nor the debate that provoked him to undertake that work were included. ${ }^{5}$

A couple of further terminological notes before we proceed to describe the exploratory study in detail. First, 'genetic determinism' is a problematic term for a host of reasons, among them its historical origins as a term of abuse rather than self-description (cf. 'social Darwinism', 'racism' etc.). ${ }^{6}$ Here it refers to a stance or attitude towards genes as overriding 'super causes' in the making of bodies and minds; or, looked at from the other direction, towards bodies and minds as in the main the product of the action of 'genes for' bodily and mental constituents. Kostas Kampourakis' definition well captures our use of 'genetic determinism': 'genes invariably determine characters, so that the outcomes are just a little, or not at all, affected by changes in the environment or by the different environments in which individuals live' (Kampourakis 2017 , p. 6). So construed, genetic determinism is a matter of degree, marked at one pole by default credulousness towards specific and general claims about the all-determining power of genes, and at the other pole by default scepticism towards such claims (such scepticism being, of course, not at all the same thing as default environmental determinism). ${ }^{7}$ The hypothesis under investigation in the Leeds exploratory study is that the teaching of Mendel's experiments with hybrid peas - where visible traits are all-or-nothing, and everything depends on 'genes for' those traits, and on nothing other than those genes - as foundational for understanding genetics is an eliminable source of support for the genetic-determinist attitude. In connection with genetic determinism we will also refer in what follows to 'genetic optimism', by way of capturing the inference that people who believe that genes are 'super causes' are also likely

\footnotetext{
${ }^{5}$ For readers familiar with the received historiography on the Mendelian-biometrician debate, it is worth stressing that, although Weldon and the UCL mathematician Karl Pearson were firm allies in the cause of biometry and gradualist Darwinism, they were very different sorts of thinker on inheritance. Where Weldon was a biologist first and last, Pearson was a combination of mathematician, positivist philosopher and statist socialist (see Porter 2004). A 'Pearsonian' curriculum in introductory genetics would, needless to say, bear little resemblance to a Weldonian one.

${ }^{6}$ For an entertaining dismissal of the term as naming something anyone ever believed, see Dennett 2003.

${ }^{7}$ Kampourakis helpfully distinguishes genetic determinism from two related terms: 'genetic essentialism' ('genes are fixed entities, which are transferred unchanged across generations and which are the essence of what we are by specifying characters from which their existence can be inferred') and 'genetic reductionism' ('genes alone provide the ultimate explanation for characters, and the best approach to explain these is by studying phenomena at the level of genes') (Kampourakis 2017, p. 6).
} 
to believe that increased understanding of genes, and greater ability to manipulate them, will be a 'super solution', especially in relation to human health and medical developments.

The other term needing comment is 'interaction'. In Kitcher's essay likening genetic determinism to the undead, he noted that 'Lewontin's own response to the continued reemergence of genetic determinism has been to deny the correctness of the interactionist credo, the conventional wisdom to which purveyors of determinist claims retreat in the face of criticism' (Kitcher 2001, pp. 283-284). As Kitcher explained, that denial amounts to a repudiation of the idea that there are ever two differentiated entities, 'genes' and 'environment', which then go on to have 'interactions'. Rather, for Lewontin we ought, in dialecticalMarxist fashion, to liberate our thinking from all such reductive reifications and embrace the reality of process. Kitcher finds all of that needlessly obscure, in ways that jeopardize the larger cause of battling genetic determinism. Our own sympathies extend to both sides in this debate; but for present purposes, we are, like Kitcher, using 'interaction' as a marker for a point of view that is not just an intellectually upmarket version of genetic determinism.

\section{The Weldonian Teaching Intervention}

\subsection{Study Context and Participants}

The basic shape of the study was simple. We compared two groups of undergraduate students, one taking a typical foundational genetics course, the other taking a course built around the Weldonian curriculum. Before and after teaching, we used a specially designed questionnaire to assess the attitudes of both groups to genetic determinism. Our double-barrelled prediction was that, as measured by the questionnaire, the level of genetic determinism of the students in the Weldonian course would on average be lower at the end of teaching compared to their initial views, whereas for students in the Mendelian course, the level of genetic determinism would at best remain the same.

For the sake of comparability of data, we wanted the two courses to be as similar as possiblediffering only in respect of the Mendelian versus Weldonian emphases - and likewise wanted the students in those courses to be as similar as possible - in the first instance, by being in the same year of the same degree. As we set up the study, however, it became clear to us that practical constraints required some rethinking on both fronts. To consider the courses first: our original intention was for our Weldonian course to mirror, as closely as possible, the existing first-year, start-with-Mendel 'Introduction to Genetics' module at the University of Leeds. ${ }^{8}$ But as the construction of the Weldonian course proceeded over the academic year 2012-13, we realized that no close mirroring was possible, for two related reasons. First, the Mendelian course is massive, consisting of 33 1-h lectures and 33 -h problem classes. The task of creating a Weldonian module of the same structure and scale, from scratch, proved not to be the work of a year, which was all the time that we had available. Second, even if we had been able to build a Weldonian module along those imposing lines, it would not have been feasible, as was always our plan, to ask volunteers to undertake such a workload for no academic credit. So the syllabus content of the Weldonian course as delivered - to be summarized shortly — was not, in every way but Mendelian-versus-Weldonian emphasis, the same. Nevertheless, it was true to our vision for a

\footnotetext{
${ }^{8}$ On genetic determinism in the textbook used in the Leeds Mendelian course, iGenetics: A Mendelian Approach by P. Russell, see Jamieson and Radick 2013, 579 \& 592. The course structure and content - which is largely molecular in focus after the Mendelian beginning - can be sampled via the University of Leeds website, e.g. at https://leedsforlife.leeds.ac.uk/Broadening/Module/BLGY1232.
} 
course that, in marked contrast to standard Mendelian introductory instruction, stressed developmental context and phenotypic variability from the beginning and throughout.

Turning next to the students: as we were using a first-year biology module as our Mendelian course, we intended to recruit student volunteers for our Weldonian course from among the biology first-year student population. In the end, however, the students who were eventually recruited onto the Weldonian course - hereafter the 'intervention group'-were second-year undergraduates in the humanities. We had to recruit from humanities students because our university deemed it unethical for us to interfere in a risky way with the credit-bearing biology studies of biology undergraduates, and further ruled out our recruiting undergraduates studying other sciences (and STEM courses generally) on the view that these students tend to have extensive laboratory/ practical sessions which would make for unacceptable timetabling difficulties. And we recruited students entering their second year because we realized belatedly that it would be inappropriate to burden incoming first-year undergraduates with the decision as to whether they could manage the additional workload right at the start of their university career. Needless to say, and notwithstanding the incomparabilities thereby introduced into the study data, these sorts of students, representing the non-experts who will be the genetically literate citizens of the future (a class vastly larger than the class of biologists), are of considerable interest in their own right.

In order to recruit student volunteers onto the Weldonian course, we contacted all first-year students in the Faculty of Arts via e-mail towards the end of the 2012-13 year, whilst further announcements via the Virtual Learning Environment and guest appearances at lectures were delivered to specific first-year modules with large cohorts of students. Interested students were then provided with an information sheet/consent form, explaining the aims of the project and what would be expected of them. Signed consent was obtained from all participating students. Early the next academic year, we recruited first-year biology students taking the 'Introduction to Genetics' module, which was taught by an experienced member of the teaching staff in Biological Sciences at the university, as our 'comparison group'. For this group, students enrolled on the module were the only target; their interest was also solicited via the Virtual Learning Environment and in person. Information and consent for this group were incorporated into the online genetic determinism questionnaire (see below).

As for rewards: the intervention students were each offered a $£ 100$ cash payment on completion of the course and all associated activities, including the survey; whilst the comparison students each received a $£ 15$ e-retail voucher of their choice on completion of the questionnaire for the second time. All aspects of the study were assessed and approved by the appropriate Ethics Committee at the University of Leeds.

The intervention group comprised 28 students, all of whom completed the course and all associated surveys and tests. The comparison group, fortuitously, also contained 28 students (35 students completed the initial survey but 7 failed to complete the survey after teaching and therefore were excluded from data analysis).

\subsection{The Weldonian Curriculum}

\subsubsection{Structure and Themes}

In order to accommodate the time limitations of both volunteer students and project staff, we decided that 1050 -min lectures, ${ }^{9}$ plus associated reading and online activities such as quizzes

\footnotetext{
${ }^{9}$ In the event, due to illness during the teaching period, one lecture had to be cancelled and the remainder reorganized, so the total number of lectures given was nine.
} 
and blog entries, would be the maximum practicable workload. In order to build a cohesive and self-contained curriculum within these limits, and in a way that reflected our desired Weldonian emphases whilst holding students' attention, we chose to focus our coverage on the human-genetics component of the standard curriculum, using human examples where possible and appropriate (e.g. in introducing the structure and function of DNA), and only including those genetic technologies necessary to explain genetic testing for human diseases.

In harmony with Weldon's Theory of inheritance, the Weldonian curriculum stressed two themes whilst tacitly but strategically downplaying a third:

i. The importance of environment: students were introduced at the very beginning of the course to the concept of both internal and external environments and the effects these can have on the expression of genes. The fact that genes exist only in organisms, and the fact that organisms exist in varying environments, were continually emphasized. In the very first lecture, for example, the differential development of queen and worker honey bees was discussed - the same genome produces distinctly different organisms, depending on the external environment - and this was contrasted with the case of the $O b$ gene in the mouse - mice in identical environments, with identical food, will become fat or not depending on which variation of a particular gene they carry.

ii. Emphasis on developmental processes rather than transmission patterns: the modularisation of university courses has consolidated the divide between transmission genetics and developmental biology, such that many genetics students are required to study very little developmental genetics. Built into the Weldonian course was the conviction that a basic understanding of how a fertilized egg becomes a functional multi-cellular organism is the key to a student's coming to have a secure conception of how genes act and interact in the real world.

iii. Downplay of the concept of dominance and 'gene for' talk: students were introduced to the concept of alleles and the variety of ways in which different alleles can interact in a diploid organism, but with an emphasis throughout on how the contexts of those interactions can condition their outcomes. The vocabulary of 'gene/s involved in' was used consistently throughout the course in place of 'gene/s for'. Mendelian principles were used where appropriate (in pedigree analysis, for example); but there was no explicit reference to Mendel or to his experiments with peas.

An especially notable feature of the resulting curriculum is that the overall structure deviates from the standard pattern of starting the students with genetically simple examples and only gradually adding complexity. Again, this simple-to-complex trajectory, for all its abundant virtues, runs the risk of creating students who cling to the simple (see Jamieson and Radick 2013, p. 578). Instead — and in line with Dougherty's (2009) recommendations (although we reached the same conclusion independently) - our students were introduced to the complexity of genetic influences in the first lecture. In order to demonstrate the difficulty of explaining complex disorders, the students were shown a diagram with the range of different factors that we know can influence the likelihood of a person suffering from cardiovascular disease or 'CVD' (see Fig. 1).

The links between the factors and the disease, and between different factors, were then gradually filled in (solid lines for confirmed causal links, broken lines for suspected ones), one by one, until the diagram looked like Fig. 2.

It was explained that there are some identified, single-gene effects within this network (green, solid lines) and other correlations that might eventually lead to the identification of 


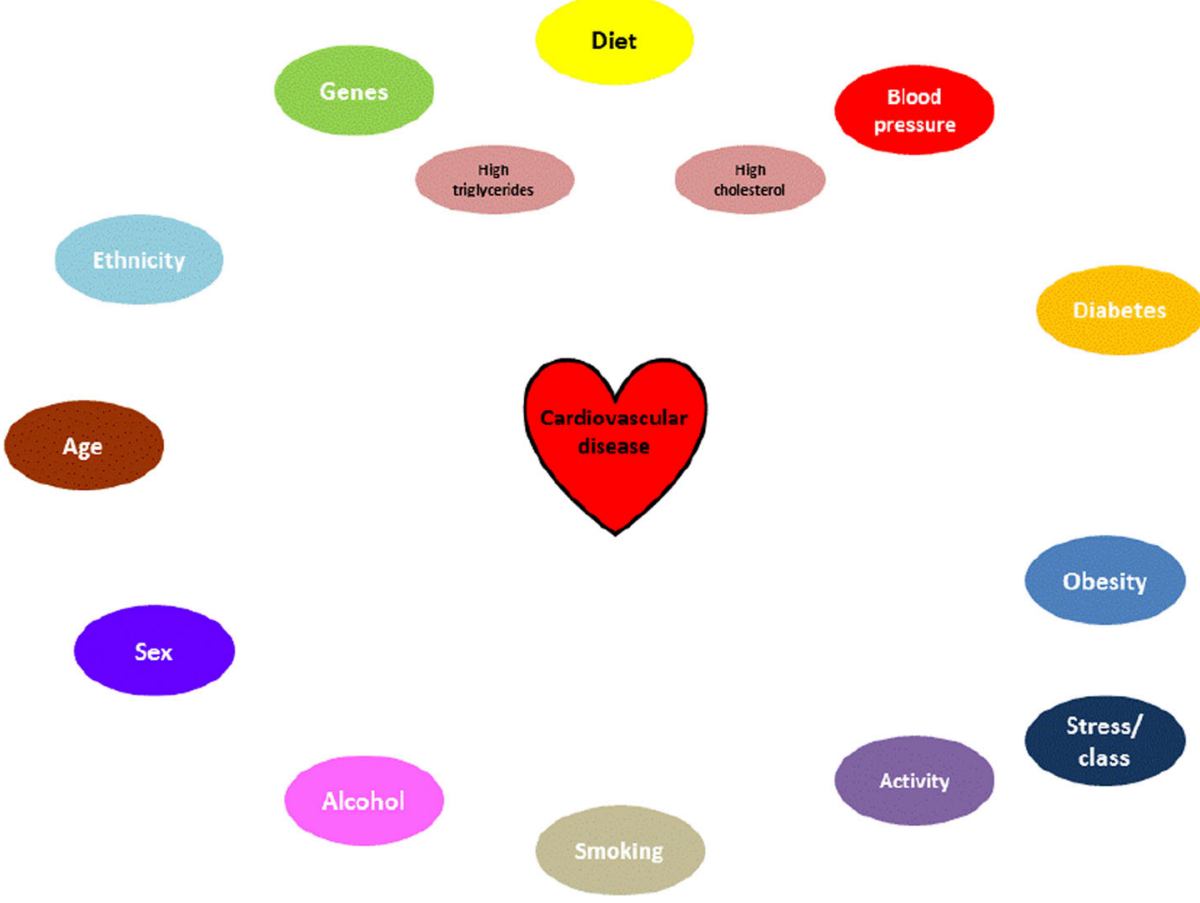

Fig. 1 Schematic representation of the factors affecting cardiovascular disease; from a PowerPoint slide used in the Weldonian curriculum

other genes involved in the disease. Students were then asked to consider what the 'gene for' CVD might be, and whether they thought that we will ever have a reliable, genetic 'cure' for this condition. Students generally agreed that this was unlikely.

The strong emphasis in the Weldonian curriculum on the effects of the environment could, we were aware, have tipped the balance too far and led to students emerging as environmental determinists rather than genetic determinists. To guard against this, throughout the course we strove to represent genes and environment as equally important.

\subsubsection{The Lecture Sequence}

The module document, lecture handouts and PowerPoint slides with lecture 'voiceover' can be downloaded for free from the Genetics Pedagogies Project website. ${ }^{10}$ In outline form, the lectures, which were written and delivered by Jamieson, covered the ground as follows:

Lecture 1: What is genetics?: A broad introduction to the course, including the following:

- The questions raised by biological inheritance

- What is the environment? External vs internal

- Inheritance and the environment

- Essential terminology for the course

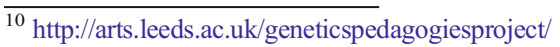




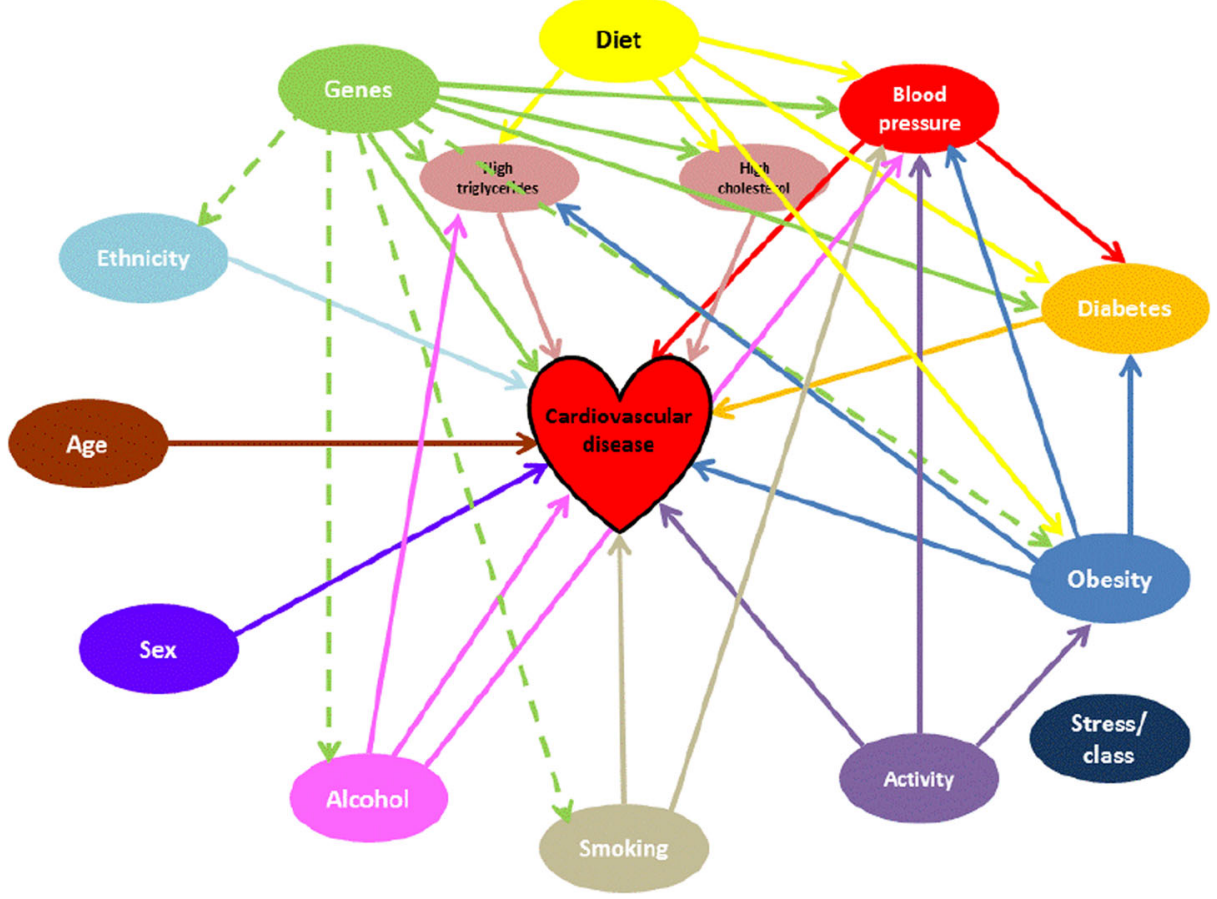

Fig. 2 The web of causal links connecting the factors affecting cardiovascular disease and the disease itself

Lecture 2: Basic development: The important of development in understanding inheritance, including the following:

- How do we get from a single cell to a multi-celled, differentiated organism?

- How do cells containing the same basic genetic material develop into a wide range of celltypes?

- Environmental influence, contingency and chance in development.

Lecture 3: How does it all work? (How genes are expressed 1): An introduction to the basic 'mechanics' of DNA, including the following:

- DNA structure (and its consequences)

- Molecular processes associated with gene expression: replication, transcription, translation

- The genetic code

- Gene regulation

Lecture 4: How does it all work? (How genes are expressed 2): A review of how changes in any of the processes covered in lecture 3 can affect the ways in which a gene is expressed, including the following:

- Mutations

- Replication errors

- Mutagens and their effects (chemical, radiation) 
- Epigenetics

Lecture 5: Chromosomes, linkage and genetic maps: How DNA is packaged into chromosomes, the structure of the genome at the chromosomal level and how this allows genetic mapping, including the following:

- Mitosis and meiosis

- Chromosomes and karyotypes

- Linkage and recombination (linkage distances and recombination frequencies)

- Changes in chromosome structure and number

Lecture 6: Sex determination and sex-linkage: How even such an apparently straightforward trait as sex is, in fact, much more complicated, including the following:

- Environmental sex determination

- Genotypic sex determination

- Human sex-determination: primary/secondary

- Disorders of sex determination

- Environmental effects

Lecture 7: Patterns of inheritance: How, in some cases, observed patterns of inheritance can help us to understand and predict how traits are inherited, including the following:

- Model organisms - engineered systems for studying inheritance: benefits and limitations

- Dominance and recessiveness

- Use of pedigrees in studying inheritance

- Modes of inheritance: autosomal dominant/recessive; Y-linked; X-linked dominant/ recessive

Lecture 8: Factors affecting patterns of inheritance: Using examples of human disorders, this lecture shows how gene-gene and gene-environment interactions can affect the way a particular gene is expressed, giving a range of phenotypes and complicating apparent patterns of inheritance:

- Pleiotropy

- Penetrance/expressivity

- Epistasis

- Lethal mutations

- Locus heterogeneity

- Imprinted genes

Lecture 9: What does it all mean?: This final lecture considers some of the social and ethical aspects and consequences of the course material, including the following:

- Genetic testing 
- Methods and examples

- Purposes of genetics testing

- Who should be tested?

- 'a gene for'... autism? homosexuality? etc.

- Implications for individuals/society

- Problems of genetic determinism

Again, where appropriate, the material covered was similar to that in the Leeds 'Introduction to Genetics' module.

\subsubsection{Associated Materials}

Beyond the lectures themselves, two preparatory readings were made available for each lecture: one 'straight' genetics reading, mainly selected from the journal $\mathrm{Na}$ ture's online resources; and one 'enhanced' reading, from carefully chosen popular works or from the philosophy of biology literature, addressing ethical issues etc. (so, e.g. for the first lecture, the required readings were Lewontin 1982, pp. 14-28 and Pinker 2009). The students were also given several blog tasks during the course, where they were asked to consider an issue in genetics and write a short blog entry encapsulating their thoughts on the topic. For example, in response to reports in the UK press of a government aide misusing the results of Robert Plomin's research into intelligence, ${ }^{11}$ the students were asked to explore the subject on the web and to report their views. Finally, the students were encouraged to explore the lecture and reading topics more broadly, and to this end the module document offered a short list of additional readings, useful web sites, online activities and so on in connection with each lecture.

\subsection{Data Collection}

\subsubsection{Assessing Genetic Determinism Holistically}

The attempt to quantify levels of genetic determinism has occupied a minor research industry in the sociology of genetic knowledge (see, e.g. Aikenhead and Ryan 1992; Keller 2005; Castéra and Clément 2014). Having considered a number of existing instruments we found none that were entirely suitable for our purposes, being either too broad or too specific, or requiring data analysis beyond the statistical skills of our team. We therefore decided that it would be more appropriate to design our own questionnaire, aiming for a holistic assessment, containing questions that would more specifically address the particular experiences of our study population, and that would generate both quantitative and qualitative data whilst being amenable to relatively simple analysis. The categories were chosen to explore different aspects of students' knowledge and attitudes about genetic issues (see below for more information on the individual categories) and the questions were based on information that students without former specific genetics education could reasonably be expected to have encountered, using

\footnotetext{
${ }^{11}$ See, e.g. 'Michael Gove held talks with "IQ genes" professor', Independent 12 October 2013, http://www. independent.co.uk/news/education/education-news/michael-gove-held-talks-with-iq-genes-professor- 8876500 . html
} 
ideas and examples commonly raised in news reports, popular science sources and everyday life.

In brief, the survey — which was delivered via Bristol Online Surveys ${ }^{12}$ — was divided into six sections:

\section{i. 'Your details' (participant information)}

This section collected information on age, gender, which degree programme the student was on, previous qualifications in biology or other sciences, and whether they had any personal experience of genetic conditions/illness.

ii. 'Your opinions' (data on genetic determinism per se)

Here the aim was to directly test students' views on the relative influence of genes and environment. The questions - all answered on a Likert scale - were worded so as to allow students to give answers that favoured either the causality of genes or the causality of environment. For example:

- A person's genetic makeup has no influence on intellectual abilities (such as intelligence or concentration)

- Cloning can produce an identical copy of an animal — so you could recreate a much-loved pet, or a very valuable race-horse, for example

- Apart from artificial characteristics (for example, hair style, clothing, accidental scars) it is not possible to tell identical twins physically apart

\section{iii. 'Your knowledge' (data on basic knowledge of genetics)}

This section contained a series of questions testing basic knowledge that even those with no formal post-compulsory education in the subject might have gathered from pre-16 school, popular reports, television documentaries and so on. The intention was to give a pre-test measure of the students' knowledge. The questions all took the format of a statement with 'true'/‘false'/‘do not know' options for answers. For example:

- Genetic information is carried on DNA

- Individuals inherit half of their DNA from their mother and half from their father

- There is a separate gene for each characteristic of a human being

iv. 'Genetics, health and disease' (data on genetic optimism)

The aim of this section was to test the extent to which students believe that genetics holds the answer to problems of human health and well-being. Again, by exploring whether students think that genetic developments provide 'super solutions' to medical problems, we can infer the extent to which they hold genes to be 'super causes'. The questions were based on predictions made at the time the human genome sequence was completed and took the format of a statement with the options:

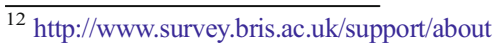


- 'already happened'

- 'not yet but likely in the near/medium-term future'

- 'not yet but likely in the distant future'

- 'unlikely to ever happen'

For example:

- We will be able to use a person's own cells to clone replacement organs for that person (e.g. kidneys, heart) to allow organ transplants without the risk of rejection

- Tailor-made prescription medicines for individuals will reduce unwanted side-effects

- We will be able to manufacture artificial replicas of natural human proteins that can be used to treat diseases (e.g. insulin to treat diabetes)

For all questions in sections (ii) - (iv), students were given clear instructions to differentiate in their answers between not understanding the question itself (due to unfamiliar vocabulary, for example) and understanding the question but being undecided as to their opinion about it. They were also given space and encouragement to comment (in free text) on any question should they wish to do so.

\section{v. 'Genetics and society' (data on genetic reasoning)}

This section comprised two questions which invited text-based answers from the students. The aim was to capture views which the survey might otherwise have missed. The two questions were deliberately chosen to touch on topics that students might have some familiarity with via media reports (past or present), and that they could relate to in terms of their own intellectual or athletic abilities. One question, on Jamaican sprinters, related to physical traits, and the other, on Francis Galton's work on the professions, to intellectual traits, the better to allow us to see whether there was a difference in attitudes about the two types of trait.

\section{vi. 'Your opinions on this survey'}

This section contained questions about the user-friendliness of the survey.

The body of the survey was identical for both intervention and comparison groups and for both before and after teaching, with only the introductory material differing. The survey questions are available in an Appendix.

\subsubsection{Pilot Testing of the Survey, with Remarks on Reliability and Validity}

The survey was tested and refined several times before being administered to the study participants before and after their respective courses. The three main groups who completed test surveys were, in chronological order: graduate students and colleagues in the authors' home department (this was primarily to test the general structure and tone of the survey and to reveal any practical problems in its operation); participants in a mid-project workshop (these were experts in educational research, genetics pedagogy, and social and historical research, who provided feedback on both the content and structure of the survey); and first-year humanities students (volunteers for this testing were recruited via e-mail and, as an incentive, their names were entered into a draw to win an e-retail voucher). 
A propos of the survey's reliability, assessed by the standard statistical measures, Cronbach's alpha and test-retest values in the comparison group were calculated for responses to the questions constituting sections (ii), (iii) and (iv). The alpha values were, respectively, $0.4675,0.5949$ and 0.5702 ; the test-retest values were, respectively, $.63, .578$ and .63 . These values are considerably lower than ideal, suggesting that, in future, we should investigate the possibility that the survey as currently constructed evaluates what are actually different dimensions of genetic determinism. A propos of the survey's validity, we note that, for the reasons given, although none of the published genetic determinism questionnaires seemed to us wholly fit for purpose, our own version-itself examined in draft form by experts in the field-is but a variation on its predecessors, and to that extent partakes of their status as genuinely measuring what they purport to measure. ${ }^{13}$

\subsubsection{Assessing the Weldonian Curriculum qua Ordinarily Effective Course}

In order to assess the effectiveness of the Weldonian curriculum in imparting knowledge about genetics, the intervention group were given the equivalent of the summative end-of-semester exam that the comparison group took. This took the form of a 1$\mathrm{h}$, multiple-choice exam, delivered online. Where appropriate to the lecture material, questions identical with those given to the comparison group in their formal exam were used (taken from a range of previous exam papers for the module). Otherwise, questions were created in a similar format and of a similar type to those taken by the comparison group, but reflecting the Weldonian course content.

\section{Results}

\subsection{The Multiple-Choice Exam}

The range of results on this exam, given to the intervention group at the end of teaching, was similar to that expected for this group of students in their normal, credit-bearing modules, with no students failing the test, and 50\% gaining a mark in the first/upper second-class range (see Fig. 3).

\subsection{Survey Responses Before and After Teaching}

\subsubsection{Methods of Analysis}

We outsourced the statistical evaluation of the quantitative survey responses (sections ii-iv) to Cheryl Craigs, a university colleague specializing in the statistical assessment of health research. In all cases, she took a $p$ value of less than 0.05 to be statistically significant, with statistical significance based on a two-tailed test. The software used was SPSS version 22. Pretest group comparisons for age, sex and personal experience of genetic conditions/illnesses in the family were made using chi-squared statistics. For responses to questions in section (ii) of

\footnotetext{
$\overline{13}$ On the general need for research on the genetics curriculum to do better when it comes to vetting the reliability and validity of the assessments used, see Campbell and Nehm 2013.
} 
the survey, on genetic determinism per se, the five options from 'strongly disagree' to 'strongly agree' were given values from -2 to +2 , then analysed via a fourfold method: first, pre-test individual question responses were compared between groups using the Mann Whitney test; second, comparison of total scores at pre-test and post-test for each group was assessed using the paired $t$ test; third, difference between total pre-test scores between groups was assessed using the independent $t$ test; and fourth, difference between change in scores between groups was assessed using the F-test, based on ANCOVA, controlling for pre-test total score. For the 'true'/‘false'/'do not know' responses in section (iii), on genetic knowledge, correct answers were given a value of 1 and incorrect or unspecified ('do not know') ones a value of 0 . The same fourfold method was then carried out, but with the chi-squared test used in place of the Mann-Whitney test. And for section (iv), on what we have called 'genetic optimism', responses were given a value of 3 ('already happened'), 2 ('not yet but likely in the near/ medium-term future'), 1 ('not yet but likely in the distant future') or 0 ('unlikely ever to happen'), with their analysis proceeding as with the 5-point Likert scale responses.

By way of initial analysis of the responses to the text-based questions on genetic reasoning in section $\mathrm{v}$, we sorted the responses into three categories: 'disagree with the statement', 'agree with the statement' or 'both', i.e. agree and disagree, e.g. 'This is true to some extent but.....', often mentioning both genetic and environmental factors. Then, according to the students' reasons for their agreement/disagreement etc., we further sorted the responses in each category into five subcategories: 'evidential' (emphasizing problems with evidence, especially counterexamples to the statements), 'biological' (stressing innateness, selection, evolution, rapidly twitching muscles, connectivity in the brain etc.), 'environmental' (stressing training, education, motivation, human decisions etc.), 'multiple' (where they mentioned more than one sort of reason) or 'no explanation' (where the response was a plain 'Yes, this is true' or similar). That made for 15 classifications in all.

\subsubsection{Findings}

Genetic determinism per se (section ii): For this section of the survey, the pre-test data show that although, on average, members of the comparison group assigned less weight to genetic factors than did members of the intervention group, the difference between the groups was not statistically significant. The mean for the comparison group was -5.66 . The mean for the intervention group was -3.87 . The combined mean was -4.87 (see Fig. 4 - bear in mind that the further to the left on the graph, the lower the genetic determinism score).

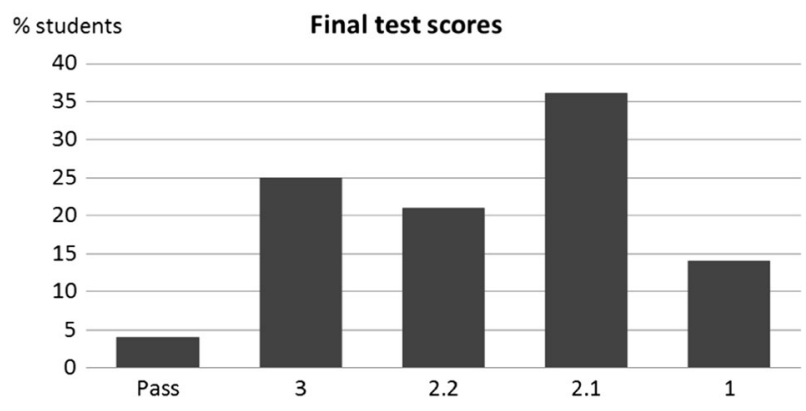

Fig. 3 Scores on the multiple-choice exam at the end of the Weldonian course ( 1 is roughly equivalent to an $\mathrm{A}$ in the American system, 2.1 to a B+ and so forth) 
The post-test data for the comparison group reveal them to have become fractionally more determinist about genes after teaching than before; but the difference with this group's pre-test scores is not statistically significant. Adjusted to take into account the inevitable dropouts (there were seven, who, as a group, gave significantly less weighting to genetic factors), there was a change of mean from -4.46 to -4.29 . The overall pre-test and post-test profiles for this group thus look largely the same (see Fig. 5).

By contrast, the post-test data for the intervention group reveal a statistically significant reduction in genetic determinism, with a shift of the mean score from -3.87 to -6.75 (see Fig. 6).

Turning finally to the remaining sections of the survey in turn:

- Basic knowledge (section iii): There was no significant difference in the pre-test scores of the comparison and intervention groups (the average in both was about 10 correct answers out of 16 questions) - a surprising result, as $100 \%$ of the comparison group had studied Alevel biology or equivalent at secondary school, whilst less than $20 \%$ of the intervention group had done so. Both groups showed a small but significant improvement in scores after teaching (by approximately 1 mark), with no significant difference between the groups in this respect.

- Genetic optimism (section iv): Again, there was no significant difference in the pre-test scores of the two groups, with both moderately optimistic to the same extent (a mean score of 15.5 out of a maximally optimistic 24). The post-test scores, however, were a different story. The comparison group score was up 0.96 , and the intervention group score was down 0.96 . Neither change is itself significant; but the difference in change between the two groups is statistically significant.

- Genetic reasoning (section v): For the Jamaican sprinter question, pre-test responses from the comparison group show a marked peak for disagreement with the statement on biological grounds (see Table 1 below). Students in this group did not think that the success of the sprinters was due to selection during slavery, and they gave biological explanations for this

\section{Genetic determinism: Pre-test score comparison}

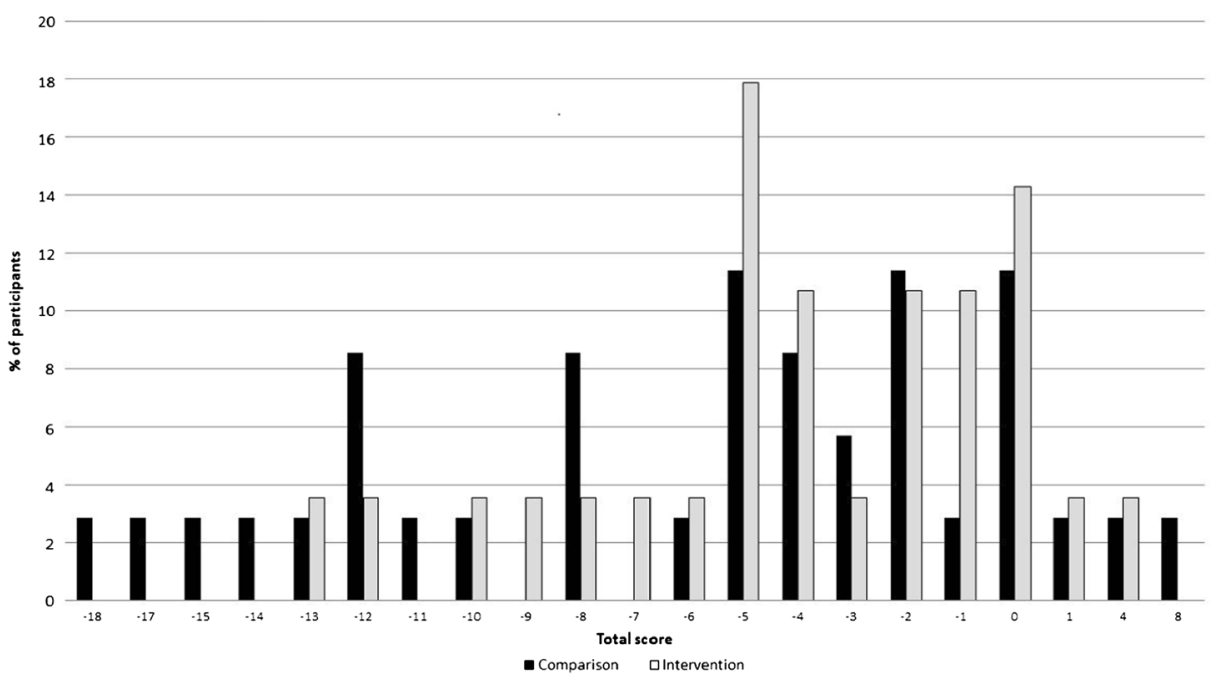

Fig. 4 Pre-test scores on genetic determinism per se in both groups 


\section{Genetic determinism: Comparison group}

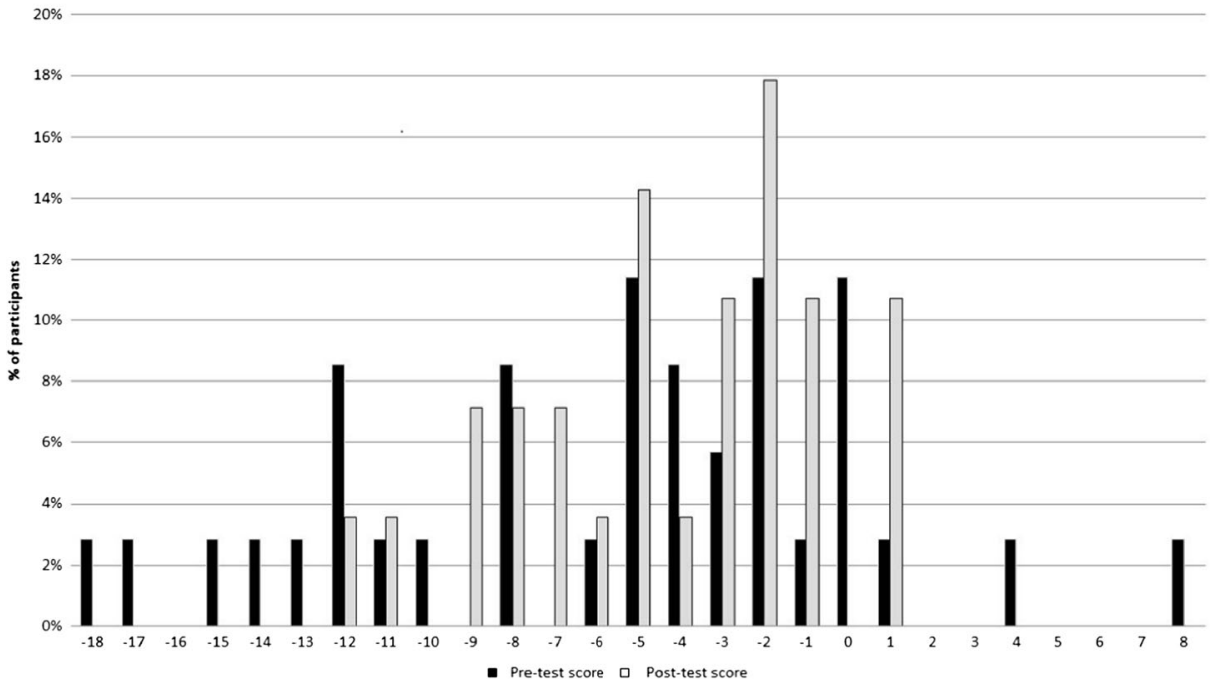

Fig. 5 Pre- and post-test scores on genetic determinism in the comparison group, taught a Mendelian curriculum

view, for instance, that natural selection requires a longer time span to fix a trait than the time since slavery; that slave owners would not have been selecting the specific traits that make a good sprinter; and so on. By contrast, pre-test responses from the intervention group had a peak at agreement with the statement on biological grounds. They largely accepted that the sprinting success was due to selection during slavery, and they gave biological explanations, most commonly that the selection of slaves in the slave market would have been a process

\section{Genetic determinism: Intervention group}

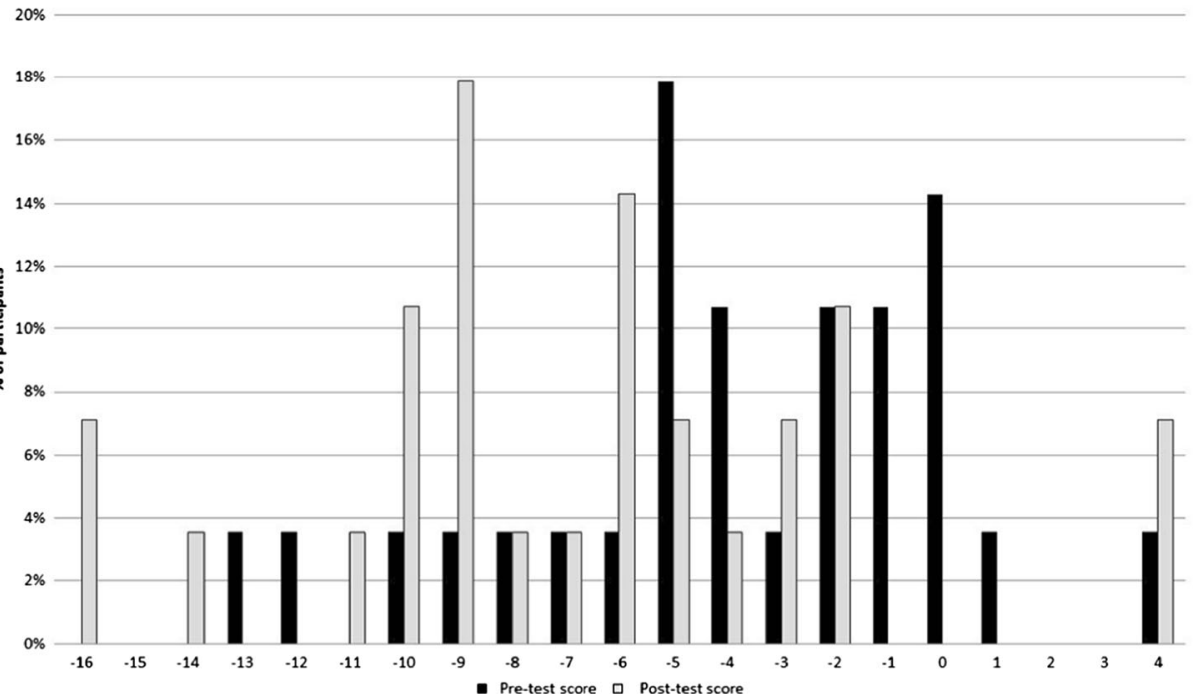

Fig. 6 Pre- and post-test scores on genetic determinism in the intervention group, taught a Weldonian curriculum 
like natural selection, and with like effects. After teaching, this peak reduced but did not disappear, though there was an increase in mention of the environment in the intervention group compared with their pre-test answers (in other words, they still largely agreed that the sprinting success was due to selection during slavery, but they were more inclined to also mention environmental factors as a minor contributory factor). For the Galtonian-professions question, the comparison and intervention groups were much more in accord and there was an overwhelming emphasis on environmental explanations in both groups, both before and after teaching, with very little mention of biological explanations. A very small minority of the students in all groups agreed with the statement (see Table 2).

Table 1 Pre- and post-test responses to the Jamaican sprinter question in comparison and intervention groups (percentage of students in each group responding in each category; peak values in grey)

\begin{tabular}{|c|c|c|c|c|}
\hline $\begin{array}{l}\text { Answer and explanation } \\
\text { type }\end{array}$ & $\begin{array}{l}\text { Comparison } \\
\text { group pre- } \\
\text { test }\end{array}$ & $\begin{array}{l}\text { Comparison } \\
\text { group post- } \\
\text { test }\end{array}$ & $\begin{array}{l}\text { Intervention } \\
\text { group pre-test }\end{array}$ & $\begin{array}{l}\text { Intervention } \\
\text { group post-test }\end{array}$ \\
\hline $\begin{array}{l}\text { Disagree (no } \\
\text { explanation) }\end{array}$ & $3 \%$ & 0 & 0 & 0 \\
\hline Disagree (biological) & $34 \%$ & $14 \%$ & $18 \%$ & $14 \%$ \\
\hline $\begin{array}{l}\text { Disagree } \\
\text { (environmental) }\end{array}$ & $6 \%$ & $7 \%$ & 0 & $3.5 \%$ \\
\hline Disagree (evidential) & $6 \%$ & $7 \%$ & $3.5 \%$ & 0 \\
\hline Disagree (multiple) & $3 \%$ & $17 \%$ & $7 \%$ & $10.5 \%$ \\
\hline Sub-total & $52 \%$ & $45 \%$ & $28 \%$ & $28 \%$ \\
\hline Agree (no explanation) & $8.5 \%$ & $7 \%$ & $3.5 \%$ & 0 \\
\hline Agree (biological) & $8.5 \%$ & $17 \%$ & $46 \%$ & $25 \%$ \\
\hline Agree (environmental) & 0 & 0 & 0 & 0 \\
\hline Agree (evidential) & 0 & 0 & $3.5 \%$ & 0 \\
\hline Agree (multiple) & 0 & 0 & 0 & $10.5 \%$ \\
\hline Sub-total & $17 \%$ & $24 \%$ & $54 \%$ & $36 \%$ \\
\hline Both (no explanation) & 0 & 0 & 0 & 0 \\
\hline Both (biological) & $3 \%$ & $3 \%$ & $3.5 \%$ & $10.5 \%$ \\
\hline Both (environmental) & $11 \%$ & $7 \%$ & 0 & $10.5 \%$ \\
\hline Both (evidential) & 0 & 0 & 0 & 0 \\
\hline Both (multiple) & $14 \%$ & $21 \%$ & $14 \%$ & $14 \%$ \\
\hline Sub-total & $28 \%$ & $31 \%$ & $18 \%$ & $36 \%$ \\
\hline
\end{tabular}


Table 2 Pre-test and post-test responses to the Galtonian-professions question in the comparison and intervention groups (percentage of students in each group responding in each category)

\begin{tabular}{|c|c|c|c|c|}
\hline $\begin{array}{l}\text { Answer and explanation } \\
\text { type }\end{array}$ & $\begin{array}{l}\text { Comparison } \\
\text { group pre- } \\
\text { test }\end{array}$ & $\begin{array}{l}\text { Comparison } \\
\text { group post- } \\
\text { test }\end{array}$ & $\begin{array}{l}\text { Intervention } \\
\text { group pre-test }\end{array}$ & $\begin{array}{l}\text { Intervention } \\
\text { group post- } \\
\text { test }\end{array}$ \\
\hline Disagree (no explanation) & 0 & 0 & 0 & 0 \\
\hline Disagree (biological) & 0 & 0 & 0 & 0 \\
\hline Disagree (environmental) & $31 \%$ & $38 \%$ & $36 \%$ & $36 \%$ \\
\hline Disagree (evidential) & 0 & $3 \%$ & $3.5 \%$ & 0 \\
\hline Disagree (multiple) & $3 \%$ & 0 & 0 & 0 \\
\hline Sub-total & $34 \%$ & $41 \%$ & $39.5 \%$ & $36 \%$ \\
\hline Agree (no explanation) & 0 & 0 & $3.5 \%$ & 0 \\
\hline Agree (biological) & $6 \%$ & 0 & $3.5 \%$ & $3.5 \%$ \\
\hline Agree (environmental) & 0 & 0 & 0 & 0 \\
\hline Agree (evidential) & 0 & 0 & 0 & 0 \\
\hline Agree (multiple) & 0 & 0 & $3.5 \%$ & 0 \\
\hline Sub-total & $6 \%$ & $\mathbf{0}$ & $10.5 \%$ & $3.5 \%$ \\
\hline Both (no explanation) & 0 & $3 \%$ & 0 & 0 \\
\hline Both (biological) & $3 \%$ & 0 & 0 & 0 \\
\hline Both (environmental) & $49 \%$ & $35 \%$ & $43 \%$ & $46 \%$ \\
\hline Both (evidential) & 0 & 0 & 0 & 0 \\
\hline Both (multiple) & $6 \%$ & $21 \%$ & $3.5 \%$ & $14 \%$ \\
\hline Sub-total & $59 \%$ & $59 \%$ & $46 \%$ & $61 \%$ \\
\hline
\end{tabular}

\section{Discussion}

\subsection{Limitations}

An exploratory study attempting something unprecedented, not just methodologically but disciplinarily, can be expected to have more than the usual share of limitations, and so it was here. To review some of the most glaring:

- the comparison and intervention groups were drawn from different pools (first-year biology students and second-year humanities students respectively)

- relatively small numbers of students were involved (28 in each group)

- they were taught curricula that differed not just in their Mendelian versus Weldonian emphases but also in their scales, modes of delivery and other dimensions 
- the teachers of the two groups were drawn from different pools (a male, relatively senior biologist taught the comparison group, whilst a female, relatively junior historian and philosopher of science with biological training taught the intervention group)

- the reliability and validity of the genetic determinism survey were not assessed and improved as fully as they might have been

- there was no randomizing of who taught what and who learned what

- there was no systematic collection of data on the ethnic identities and socioeconomic status of the students

- there was no systematic following-up with the group attending the Weldonian curriculum to see whether and how long any apparent effect persisted

Of course, we would have preferred to produce a methodologically impeccable study, with none of these limitations. But such a study was not, from our starting point, accessible to us, nor perhaps to anyone. The choice faced, then, was between doing the exploratory study imperfectly, in the hope that the results might prove sufficiently intriguing to open up later possibilities for improvement, and not doing the exploratory study at all, with no possibility of a better version down the line. In our concluding reflections, we shall consider some of the improvements that we foresee for the future iterations that, with guarded optimism, we now foresee.

\subsection{Interpretations}

Bearing the above in mind, in our view, the 'headline' result from our study is that students who took a Mendelian genetics course ended up as determinist about genes as they were at the start, whereas students who took an interactionist, Weldonian genetics course were less determinist about genes than they were at the start. As noted, the many and considerable differences in scale, style of delivery etc. between the two courses mean that any conclusions based on comparisons need to be handled with a high degree of caution. Even so, and especially in the light of some of the other information captured in our pre-test and post-test data, the result suggests that this pilot study merits further development. For one thing, the multiple-choice exam scores, and more generally the Weldonian lecture syllabus and the fact that undergraduate students of their own free will stuck with the lectures to the end and learned from them, show that an introductory course in genetics can emphasize complexity without thereby losing the students. For another, the pre-teaching condition of the students in our two groups was not as different as one might have expected, with both the first-year biologists (who took the Mendelian course) and the second-year humanities students (who took the Weldonian course) expressing roughly the same degree of both genetic determinism per se and genetic optimism, performing equally on questions about genetic knowledge and resisting claims about professions as genetically predestined or not, on the basis of more or less identical reasoning.

Other aspects of the survey data, whilst not directly relevant to the test of Mendelian versus Weldonian emphases which was our main purpose, are striking and merit a little comment. The pre-test level of genetic determinism in both groups of students we worked with was nothing like as cartoonishly high as a reader of the scholarly literature on student genetic determinism might guess it would be; it certainly came as a surprise to us. ${ }^{14}$ Equally surprising — and, for

\footnotetext{
${ }^{14}$ For an earlier study that found lower-than-rumoured levels of genetic determinism in the general public - and that even used 'a gene for heart disease' as a kind of cognitive probe - see Bates et al. 2003. It should be stressed, however, that the conclusion drawn was that genetic determinism is a problem for a 'sizable minority' (p. 156), not that there is no problem. We are grateful to Alan Templeton for drawing this paper to our attention.
} 
the foe of genetic determinism, equally heartening - was that the biology students were less likely than the humanities students to accept the statement about the genetic bases of Jamaican sprinter talent. Here, perhaps, the greater biological knowledge of the biology students, especially with respect to evolution, though invisible in the genetic knowledge part of our survey, came to the fore, enabling them to be critically minded in ways not available to the humanities students.

What to make of the fact that both groups of students were more or less equally disinclined to accept the statement about the genetic bases of professional success? Here, perhaps, where the biology students once again applied generic critical acumen in biological matters, the humanities students, confronting a situation far more likely to affect them than the Jamaicansprinter case, were much more critically minded than in that case. Or maybe both groups were simply sceptical about something they would rather not believe anyway.

We will consider more extensively some of the implications of this study. If we ask first what sort of advance it represents for the more circumscribed topic of scholarly inquiry into our title theme of genetic determinism in the genetics curriculum, two related points stand out. First, that inquiry has tended to concentrate on analysing all of the ways in which the genetics curriculum, especially as represented in textbooks, has become a house divided against itself, with older, determinist concepts and language mixed in unsatisfactorily, even confusingly, with newer, non-determinist concepts and language. The Leeds study suggests a means for going beyond interpreting the textbooks to changing them, and for the better. Second, it suggests how the history of biology - hitherto mainly a resource for priming appreciation of the intellectual materials that textbook writers struggled to integrate - can be part of the solution and not just part of the problem, by preserving a big-picture point of view on inheritance that made room for Mendelism without at all making way for it.

\section{Concluding Reflections}

The major difference between our Weldonian curriculum and a standard Mendelian one is a difference of emphasis, expressed in the first instance through a change in the order in which information is presented. Whereas students on a Mendelian course absorb basic Mendelian patterns and subsequently learn that these do not always hold, students on the Weldonian course were first introduced to ideas of interaction - both within the genome and between the genome and environment - and encouraged to view the Mendelian patterns subsequently learned with sensitivity to developmental contexts and phenotypic variation. The pre-test and post-test results of our survey suggest that this difference of emphasis contributed to the weakening of propensities towards genetic determinism in the group of students who took the Weldonian course - a weakening not seen in the students who took the Mendelian course.

These results are, given the many limitations of this pilot study, no more than indicative. One sign that the overall approach is nevertheless on the right track is the congruence with Dar-Nimrod and Heine's (2011) finding that one way to undermine genetic determinism is to emphasize interaction explicitly. Another sign is the evidence in Hagay et al. (2013) that the interaction between genes and environment is something that students interested in genetics especially want to know about. And the limitations are all remediable. It is not difficult to imagine a successor study that, conditions (and funding) allowing, would enable the design of a more closely comparable Mendelian counterpart course - no different in length, delivery, content, assessments, accreditation and so on — along with the recruitment of larger numbers of students with more similar educational and other backgrounds, 
to be allocated at random to the different courses. We now see lots of ways in which both the Weldonian course and the genetic determinism survey could be improved. There are also exciting prospects for, among other things, more sophisticated experimental designs, allowing us in a more fine-grained way to assess the extent to which, as we suppose, the ordering of interaction versus Mendelism is what accounts for differences at the end in levels of genetic determinism; for the development of the Weldonian curriculum not just as a university-level enrichment course but as something available in versions useful at all levels and for many different kinds of students; and for the addition to the curriculum of new elements including problem-solving, object-based learning, probability and statistics (about which Weldon himself was so passionate) and the history and philosophy of science.

Presenting our results to audiences in history and philosophy of science-our home discipline - has borne home to us how unusual our project has been as an instance of 'HPS in science education'. The usual aim in work of this kind is to introduce historical and philosophical perspectives in order to increase the capacity of student learners to think critically, creatively and humanely about scientific inquiry and the scientific enterprise. Needless to say, we are fully signed up to that mission description (see, e.g. Radick 2017). ${ }^{15}$ But we decided to keep explicit history and philosophy out of the Weldonian curriculum, for the simple reason that we wished to minimize confounding variables as far as possible, and an HPS-enriched Weldonian course would have made it harder to tell whether any reduction in genetic determinism in our students was due to the Weldonian elements or the HPS elements. Supposing, however, that, in the fullness of time, our initial results are confirmed, we will of course very much welcome the incorporation of HPS elements, including attention to Mendel himself, not as the Great Begetter but as a superbly resourceful investigator who understood his problems and results in the context of his times (see, e.g. Olby 1979; Gliboff 1999), no less than we understand ours in the context of our times. ${ }^{16}$ There might even be a case for teaching students a little about the history of the Weldonian curriculum, how it came about through research into the 'counterfactual' as well as factual history of science, and why their studying of that curriculum itself represents the taking of science's present and future in a direction it might not otherwise have gone (see Radick 2005, 2008, 2016c; Jamieson and Radick 2013). ${ }^{17}$

It is an open question how far a good Weldonian genetics education can inoculate students against the influence of genetic determinism promoted in the wider culture. But then, it may be precisely those students who will go on to challenge and ultimately change that culture, to the benefit of all. ${ }^{18}$ We close this first report on the Weldonian curriculum with this encouraging testimonial from a student who took the Weldonian course:

\footnotetext{
${ }^{15}$ An excellent conspectus on recent HPS-inflected contributions to genetics teaching can be found in Gericke and Smith 2014.

${ }^{16}$ For recent work on what Mendel's case offers students in helping them understand the nature of science, see Westerlund and Fairbanks 2010; Kampourakis 2013; Campanile et al. 2015; El-Hani 2015; Smith and Gericke 2015; Williams and Rudge 2016.

${ }^{17}$ The budding research programme in counterfactual history of science and the contingency/inevitability problem can be sampled in Soler et al. 2015. A full connecting of the counterfactual-historical dots between the historical Weldon and the Weldonian curriculum lies beyond the scope of this paper.

${ }^{18}$ On genetic determinism as underpinning racism and other forms of social prejudice, the classic statement is Rose et al. 1984, though there have been a number of empirical studies in psychology and science education since then, well summarized in Donovan 2016. On genetic determinism as undermining sound decision-making about health, illness and reproduction, see Muskavitch 2014.
} 
Having studied science all the way through high school and given it up when choosing a course at university, I was really excited when I saw a voluntary genetics course open to Arts students. I was aware that the genetics course was being taught in 'not the traditional' way, but it didn't really feel like that as I was in the lectures-it just felt like learning genetics. The course was interesting and there were times when it directly conflicted with the genetics I'd been taught when I was younger, but the Weldonian genetics correlated much more strongly with my 'real world' experience of genetics; far more than the genetics I was taught in school ever did. Two years on from completing the voluntary module I feel like my understanding of genetics is much more critical, especially when reading media reports claiming to have found a 'gene for' particular diseases, crime or athleticism. Overall, learning Weldonian genetics has allowed me to question genetic determinism to a much greater extent. (14 January 2016)

Acknowledgements Our research was supported by a grant from the Uses and Abuses of Biology programme of the Faraday Institute for Science and Religion, University of Cambridge (TWCF 0025/UAB 012). For indispensable guidance and support throughout, we are grateful to our project co-investigator Jenny Lewis. For improving comments, calculations and other forms of help with the final manuscript, we are grateful to Brian Donovan; to Matt Homer and colleagues at the University of Leeds Centre for Studies in Science and Mathematics Education; to four anonymous reviewers; and to the journal's splendidly attentive editor, Kostas Kampourakis.

\section{Compliance with ethical standards}

Conflict of interest None.

\section{Appendix}

\section{Genetics Pedagogies Student Survey}

1. Your consent

- Please tick the appropriate box below

a) I have read the information about the research project and wish to continue with the survey. I agree for the data collected from me to be used (anonymously) in relevant future research (continue)

b) I do not wish to continue with the questionnaire (withdraw from survey)

\section{Section i: Your details}

2. Name:

3. What is your age group?

- $18-20$

- 21-25

- 31-35

- $36-40$

- Over 40

- Prefer not to say 
4. Gender:

- Male

- Female

- Prefer not to say

5. Degree programme:

6. Please tell us in the space below whether you have any GCSEs or A-levels (or equivalent) in Biology or any other science-related subject (please specify the subject, but you do not need to tell us your grades). If you haven't studied any science subjects enter 'None'.

7. Do you have any personal experience of genetic conditions/illnesses in your family or close social group?

- Yes

- No

a) If yes, you can add further information here, should you wish to do so.

\section{Section ii: Your opinions}

In completing the survey, please note the following:

- All questions or statements refer to human beings, unless stated otherwise.

- The authors do not necessarily agree with all of the views expressed within the survey. There are no right or wrong answers, we are just interested in your ideas and opinions.

- We strongly encourage you to add your comments about the questions, especially if you feel that the options given do not allow you to fully express your opinion.

8. Please read the following statements about human genetics and indicate how far you agree or disagree. Use the 'don't know' option if you understand the statement but genuinely feel that you cannot give an opinion. If you don't understand the statement, or you feel that you need a different option to answer, please tell us in the comment box.

- Options: Strongly agree/agree/disagree/strongly disagree/I do not know

a. Differences in personality between two sisters raised in the same family environment are entirely biological

b. A person's genetic makeup has no influence on intellectual abilities (such as intelligence or ability to focus)

c. Cloning can produce a copy of an animal identical in all respects with the originalso you could recreate a much-loved pet, or a very valuable race-horse, for example

d. If a person is exposed to high levels of radiation - say by living near a nuclear power plant melt-down - this cannot affect their children (born years after the incident)

e. The children of musicians are more likely to become musicians themselves not because they inherit musical talent but because they follow their parents' example 
f. If it is shown that a person found guilty of a violent crime was born with a condition that affects their behaviour (for example, making it hard to control their aggressive impulses) that person should get a shorter prison sentence than otherwise

g. Identical twins are more likely to have similar personalities than non-identical twins

h. Physical diseases are more likely to have a genetic component than mental health problems are

i. Sexual orientation is biologically determined - that is, people are born gay, straight etc.

j. Apart from changes that take place after birth and throughout their lifetime (such as accidental scars, hair style, clothing, tattoos, etc.) it is not possible to tell identical twins physically apart

k. Social factors are more important than genetic factors in career success

1. Genes have a greater role in most human disease than environmental factors do

$\mathrm{m}$. Criminal behaviour is a result purely of a person's family and social circumstances

n. Women have a greater biological drive to have and care for children than men do

o. Changes in life-style (diet, exercise and so on) can never over-ride a person's genetic risk factors

p. If a person suffers from a very serious illness in their early life, leaving them with lifelong symptoms, this can affect their children. For example, if someone suffered from tuberculosis of the lungs as a child and recovered, but remained susceptible to chest infections etc., their own children (born years later) could be born with a similar susceptibility to respiratory problems

q. Cloning could never produce a completely identical copy of a human being because our development is determined by much more than just our genes

\section{Section iii: Your knowledge}

9. This section is a basic test of your existing knowledge of genetics and inheritance. Please answer the following questions 'true', 'false' or 'do not know'. If you don't understand the question (if the vocabulary is unfamiliar, for example), or if you want to give another answer, please tell us in the comment box.

a) Genetic information is carried on DNA

b) Cells of different types (e.g. nerve cells, bone cells, liver cells) in the same person contain different genetic information

c) The genetic information is organized into separate units (genes) which influence different aspects of our development

d) The environment has no effect on the way in which our genes influence our characteristics

e) Individuals inherit half of their DNA from their mother and half from their father

f) Many genes code for proteins which have important physiological functions in the body, such as haemoglobin in the blood, or insulin, which controls blood sugar levels

g) If the gene for brown eyes is dominant to the gene for blue eyes, two blue-eyed parents cannot have a brown-eyed child

h) DNA is found in every cell of the body

i) If a woman is identified as having a BRCA1 mutation, she will develop breast cancer at some point in her life 
j) Two parents are carriers for the recessive disorder, cystic fibrosis, therefore there is a 1 in 4 chance that a child they have will have the disease. If the couple already have 3 unaffected children, a 4 th child would be more at risk than the 1st child

k) There is a separate gene for each characteristic of a human being

1) Overall, more human disease is caused by environmental factors (such as diet, lifestyle, exposure to bacteria, viruses or chemicals) than by genetic factors

m) Human diseases caused by a single gene are more common than those caused by a combination of many genes

n) Cells of the same type (e.g. brain cells) in different people contain the same genetic information

o) Mutations in the DNA always lead to diseases/disorders

p) The variety we see in the human race can be completely explained by genetic differences

\section{Section iv: Genetics, health and disease}

10. The Human Genome Project completed the sequencing of human DNA in 2003. At that time, a number of claims were made about what the knowledge of an individual's DNA sequence would mean for the future of medicine and human health. Some of these claims are listed below. Please read the claims and answer whether you believe they have already happened, are likely to happen at some point in the future or are unlikely to ever happen.

- Options: Already happened/Not yet but likely in the near/medium-term future/ Not yet but likely in the distant future/ Unlikely to ever happen

a) We will be able to manufacture artificial replicas of natural human proteins that can be used to treat diseases (e.g. insulin to treat diabetes)

b) We will be able to accurately predict an individual's response to particular prescription drugs, so that medicines will be tailor-made for the individual, and therefore be more effective

c) We will be able to accurately predict a person's susceptibility to various diseases (heart disease, for example), allowing life-style change or preventative treatment that could prevent their early death

d) Tailor-made prescription medicines for individuals will reduce unwanted side-effects

e) We will be able to use gene therapy to successfully treat single-gene diseases (e.g. haemophilia)

f) We will be able to test for genetic disorders and give gene therapy before birth, so that at-risk babies will be born healthy

g) We will be able to use a person's own cells to clone replacement organs for that person (e.g. kidneys, heart) to allow organ transplants without the risk of rejection

h) We will be able to tell whether a person will become addicted to substances like tobacco or alcohol, so that the person can make more informed choices in their lifestyle e.g. someone who knew they were likely to become an alcoholic could choose not to start drinking at all 


\section{Section v: Genetics and society}

Please read each of the following passages and enter comments on your thoughts: do you agree with the ideas, or not? What are your reasons?

11. After the success of the Jamaican sprinters in the 2012 Olympics, some people claimed that the team's athletic ability is due to their ancestors having been slaves. The argument is that slaves had to be very strong and able to withstand physical hardships in order to survive, so that certain physical qualities, such as the ability to build muscle mass, an efficient respiratory system and fast muscle response (which allows for the explosive speed needed by a sprinter) are more common in their descendants, making those descendants better sprinters than other ethnic groups.

12. Francis Galton carried out extensive studies in the late nineteenth century, showing that high-status occupations - like lawyers, judges, doctors, members of Parliament, artiststended to run in families. Galton explained this by the fact that the mental qualities required to succeed in these professions - such as intelligence, creativity or self-motivation - are biologically inherited. More recently, a 2012 study in the UK claims to have identified particular genetic markers in families where many members go into leadership positions in business and politics. ${ }^{19}$

Open Access This article is distributed under the terms of the Creative Commons Attribution 4.0 International License (http://creativecommons.org/licenses/by/4.0/), which permits unrestricted use, distribution, and reproduction in any medium, provided you give appropriate credit to the original author(s) and the source, provide a link to the Creative Commons license, and indicate if changes were made.

\section{References}

Aikenhead, G. S., \& Ryan, A. G. (1992). The development of a new instrument: 'views on science-technologysociety' (VOSTS). Science Education, 76, 477-491.

Aivelo, T., \& Uitto, A. (2015). Genetic determinism in the Finnish upper secondary school biology textbooks. Nordic Studies in Science Education, 11, 139-152.

Allchin, D. (2000). Mending Mendelism. American Biology Teacher, 62(9), 633-639.

Allchin, D. (2002). Dissolving dominance. In L. Parker \& R. Ankeny (Eds.), Mutating concepts, evolving disciplines: genetics, medicine and society (pp. 43-61). Dordrecht: Kluwer.

Allchin, D. (2005). The dilemma of dominance. Biology and Philosophy, 20, 427-451.

Bates, B. R., Templeton, A., Achter, P. J., Harris, T. M., \& Condit, C. M. (2003). What does 'a gene for heart disease' mean? A focus group study of public understandings of genetic risk factors. American Journal of Medical Genetics, 119A, 156-161.

Bateson, B. (1984). William Bateson, F.R.S., naturalist[:] his essays \& addresses, together with a short account of his life. New York: Garland. (Facsimile reprint of the 1928 edition.)

Burian, R. M., \& Kampourakis, K. (2013). Against "genes for": could an inclusive concept of genetic material effectively replace gene concepts? In K. Kampourakis (Ed.), The philosophy of biology: A companion for educators (pp. 597-628). Springer: Dordrecht.

\footnotetext{
${ }^{19}$ The comment on the 2012 study was added in order to update the question and so to reduce the chance of students seeing the two questions as examples of new versus old ideas. In addition, some students in the intervention group would have encountered Galton's ideas in courses on history of science, in relation to eugenics, so it was important to show them that ideas in some respects similar to Galton's are still prevalent today.
} 
Campanile, M. F., Lederman, N. G., \& Kampourakis, K. (2015). Mendelian genetics as a platform for teaching about nature of science and scientific inquiry: the value of textbooks. Science \& Education, 24, 205-225.

Campbell, C. E., \& Nehm, R. H. (2013). A critical analysis of assessment quality in genomics and bioinformatics education research. CBE Life Sciences Education, 12, 530-541.

Castéra, J., \& Clément, P. (2014). Teachers' conceptions about the genetic determinism of human behaviour: a survey in 23 countries. Science \& Education, 23(2), 417-443.

Castera, J., Clement, P., Abrougui, M., Nisiforou, O., Valanides, N., Turcinaviciene, J., Sarapuu, T., et al. (2008a). Genetic determinism in school textbooks: a comparative study conducted among sixteen countries. Science Education International, 19, 163-184.

Castera, J., Bruguiere, C \& Clément, P. (2008b). Genetic diseases and genetic determinism models in French secondary school biology textbooks. Journal of Biological Education, 42, 53-59.

Dar-Nimrod, I., \& Heine, S. J. (2011). Genetic essentialism: on the deceptive determinism of DNA. Psychological Bulletin, 137, 800-818.

Dennett, D. C. (2003). The mythical threat of genetic determinism. In S. Pinker (Ed.), (2004) The best American science and nature writing 2004 (pp. 45-50). Boston: Houghton Mifflin.

Donovan, B. M. (2016). Framing the genetics curriculum for social justice: an experimental exploration of how the biology curriculum influences beliefs about racial difference. Science Education, 100, 586-616.

Dougherty, M. J. (2009). Closing the gap: inverting the genetics curriculum to ensure an informed public. American Journal of Human Genetics, 85, 6-12.

Dougherty, M. J. (2010). It's time to overhaul our outdated genetics curriculum. American Biology Teacher, 72, 218.

Dougherty, M. J., Pleasants, C., Solow, L., Wong, L., \& Zhang, H. (2011). A comprehensive analysis of high school genetics standards: are states keeping pace with modern genetics? CBE Life Sciences Education, 10, $318-327$.

El-Hani, C. N. (2015). Mendel in genetics teaching: some contributions from history of science and articles for teachers. Science \& Education, 24, 173-204.

Esposito, M. (2017). Expectation and futurity: the remarkable success of genetic determinism. Studies in History and Philosophy of Biological and Biomedical Sciences, 62, 1-9.

Falk, R. (2001). The rise and fall of dominance. Biology and Philosophy, 16, 285-323.

Gericke, N. M., \& Hagberg, M. (2007). Definition of historical models of gene function and their relation to students' understanding of genetics. Science \& Education, 16, 849-881.

Gericke, N. M., \& Hagberg, M. (2010a). Conceptual incoherence as a result of the use of multiple historical models in school textbooks. Research in Science Education, 40, 605-623.

Gericke, N. M., \& Hagberg, M. (2010b). Conceptual variation in the depiction of gene function in upper secondary school textbooks. Science \& Education, 19, 963-994.

Gericke, N. M., \& Smith, M. U. (2014). Twenty-first-century genetics and genomics: contributions of HPSinformed research and pedagogy. In M. R. Matthews (Ed.), International handbook of research in history, philosophy and science teaching (pp. 423-467). Springer: Dordrecht.

Gericke, N., Hagberg, M., \& Jorde, D. (2013). Upper secondary students' understanding of multiple models in biology textbooks - the importance of conceptual variation and incommensurability. Research in Science Education, 2013, 755-780.

Gericke, N. M., Hagberg, M., et al. (2014). Conceptual variation or incoherence? Textbook discourse on genes in six countries. Science \& Education, 2014, 381-416.

Gliboff, S. (1999). Gregor Mendel and the laws of evolution. History of Science, 37, 217-235.

Hagay, G., Peleg, R., Laslo, E., et al. (2013). Nature or nurture? A lesson incorporating students' interests in a high-school biology class. Journal of Biological Education, 47, 117-122.

Hogben, L. (1963). The nature-nurture issue in a contemporary curriculum of medical studies. In Science in authority: essays. (pp. 68-77). London: Unwin.

Jamieson, A., \& Radick, G. (2013). Putting Mendel in his place: How curriculum reform in genetics and counterfactual history of science can work together. In K. Kampourakis (Ed.), The philosophy of biology: a companion for educators (pp. 577-595). Dordrecht: Springer.

Kampourakis, K. (2013). Mendel and the path to genetics: portraying science as a social process. Science \& Education, 22, 293-324.

Kampourakis, K. (2017). Making sense of genes. Cambridge: Cambridge University Press.

Keller, E. F. (2000). The century of the gene. Cambridge: Harvard University Press.

Keller, J. (2005). In genes we trust: the biological component of psychological essentialism and its relationship to mechanisms of motivated social cognition. Journal of Personality and Social Psychology, 88, 686-702.

Keller, E. F. (2010). The mirage of a space between nature and nurture. Durham: Duke University Press.

Keller, E. F. (2014). From gene action to reactive genomes. Journal of Physiology, 592, 2423-2429.

Kitcher, P. (1995). The lives to come: the genetic revolution and human possibilities. London: Allen Lane/ Penguin Press. 
Kitcher, P. (2001). Battling the undead: how (and how not) to resist genetic determinism. In In Mendel's mirror: Philosophical reflections on biology (pp. 283-300). Oxford: Oxford University Press 2003.

Lewis, J. (2011). Genetics and genomics. In M. Reiss (Ed.), Teaching secondary biology (pp. 173-214). London: Hodder Education.

Lewontin, R. (1982). Human diversity. New York: Scientific American Books.

Lewontin, R. C. (1991). The doctrine of DNA: biology as ideology. London: Penguin.

Magnello, M. E. (2004). Weldon, Walter Frank Raphael (1860-1906). In The Oxford Dictionary of National Biography, online edition. Oxford: Oxford University Press.

Medawar, P.(1977). Unnaturalscience. Reprinted in Pluto's republic (pp. 167-183). Oxford:OxfordUniversity Press 1982.

Moore, D. S. (2008). Espousing interactions and fielding reactions: addressing lay people's beliefs about genetic determinism. Philosophical Psychology, 21(3), 331-348.

Morgan, T. H., Sturtevant, A. H., Muller, H. J., \& Bridges, C. B. (1915). The mechanism of Mendelian heredity. New York: Henry Holt and Company.

Muller, H. J. (1930). On the relation between phaenotype and genotype. MS (date approximate). Papers of Hermann Muller, Lilly Library, Indiana University, Bloomington.

Muller, H. J. (1947). Genetic fundamentals: the work of the genes. In Genetics, medicine, and man (pp. 1-34). Cornell: Cornell University Press.

Muskavitch, M. A. T. (2014). Genetic determinism in a post-genomic age. Integritas, 3, 1-21.

Olby, R. (1979). Mendel no Mendelian? History of Science, 17, 55-72.

Pearson, K. (1906). Walter Frank Raphael Weldon. 1860-1906. Biometrika, 5, 1-52.

Pinker, S. (2009). My genome, my self. New York Times Magazine, 7 Jan., available at http://www.nytimes. com/2009/01/11/magazine/11Genome-t.html .

Porter, T. M. (2004). Karl Pearson: the scientific life in a statistical age. Princeton: Princeton University Press.

Radick, G. (2005). Other histories, other biologies. In A. O'Hear (Ed.), Philosophy, biology and life (pp. 21-47). Cambridge: Cambridge University Press.

Radick, G. (2008). Why what if? Isis, 99, 547-551.

Radick, G. (2015). Beyond the 'Mendel-Fisher' controversy: worries about fraudulent data should give way to broader critiques of Mendel's legacy. Science, 350(6257), 159-160.

Radick, G. (2016a). Teach students the biology of their time: an experiment in genetics education reveals how Mendel's legacy holds back the teaching of science. Nature, 533(7603), 293.

Radick, G. (2016b). The enemy within [essay review of Siddhartha Mukherjee's The gene: An intimate history]. Times Literary Supplement, 25 November, 3-4.

Radick, G. (2016c). Presidential address: experimenting with the scientific past. British Journal for the History of Science, 49, 153-172.

Radick, G. (2017). The argument from science. In K. Almqvist and I. Thomas (eds.), Sapere aude: the future of the humanities in British universities. Stockholm: Ax-son Johnson Foundation.

Redfield, R. J. (2012). "Why do we have to learn this stuff?"- - a new genetics for $21^{\text {st }}$ century students. PLoS Biology, 10(7), 1-4.

Rose, S., Kamin, L. J., \& Lewontin, R. C. (1984). Not in our genes: biology, ideology and human nature. Harmondsworth: Penguin.

Santos, V. C. d., Joaquim, L. M., \& El-Hani, C. N. (2012). Hybrid deterministic views about genes in biology textbooks: a key problem in genetics teaching. Science \& Education, 21, 543-578.

Smith, M. U., \& Gericke, N. M. (2015). Mendel in the modern classroom. Science \& Education, 24, 151-172.

Soler, L., Trizio, E., \& Pickering, A. (2015). Science as it could have been: discussing the contingency/ inevitability problem. Pittsburgh: University of Pittsburgh Press.

Tabery, J. (2014). Beyond versus: the struggle to understand the interaction of nature and nurture. Cambridge: MIT Press.

Thörne, K., \& Gericke, N. (2014). Teaching genetics in secondary classrooms: a linguistic analysis of teachers' talk about proteins. Research in Science Education, 44, 81-108.

Thorpe, W. H. (1951). Evolution and Christian belief. London: British Social Biology Council.

Weldon, W. F. R. (1902a). Mendel's laws of alternative inheritance in peas. Biometrika, 1, 228-254.

Weldon, W. F. R. (1902b). On the ambiguity of Mendel's categories. Biometrika, 2, 44-55.

Weldon, W. F. R. (1904-1905). Theory of inheritance. Papers of Karl Pearson, Special Collections, University College London, Pearson/5/2/10/4.

Westerlund, J. F., \& Fairbanks, D. J. (2010). Gregor Mendel's classic paper and the nature of science in genetics courses. Hereditas, 147, 293-303.

Williams, C. T., \& Rudge, D. W. (2016). Emphasizing the history of genetics in an explicit and reflective approach to teaching the nature of science. Science \& Education, 25, 407-427. 